\title{
STRUCTURAL ANALYSIS OF TOURISM TURNOVER IN THE TOURIST RESORTS FROM ROMANIA
}

DOI: http://dx.doi.org/10.18509/GBP.2020.45 UDC: 338.486(498)"2000/2018"

\author{
Alexandra Grecu ${ }^{1,2}$ \\ Karina Andreea Gruia ${ }^{1,2}$ \\ Arina Mărunțelu1,2 \\ Oana-Elena Joița ${ }^{1,2}$ \\ Adrian Gabriel Simion ${ }^{1,2}$ \\ ${ }^{1}$ University of Bucharest-Research Center for Integrated \\ Analysis and Territorial Management; Bucharest, Romania \\ ${ }^{2}$ Faculty of Geography, University of Bucharest, Bucharest, Romania
}

\begin{abstract}
Studying the way in which the tourism turnover is distributed at territorial level, it may be a way of giving clues, regarding the economic performance achieved by the territorial systems with tourist function.

In this study we intend to analyze the tourism turnover in the tourist resorts from Romania, which are in accordance with the Government Decision no.107 of 2018, regarding the approval of the certification of some localities or parts of localities as tourist resorts of national or local interest. The analysis was based on a series of economic data for a period of 19 years, 2000-2018 which contains at the level of the territorial administrative unit and at the level of 4-digit NACE code, the evolution of the economic indicator relevant to the study, the tourism turnover. The series of data was subsequently used to create evolution charts, distribution maps and evolutions of the ranks held by the tourism turnover.

The obtained results show the contribution of the tourism sector to the total turnover from the tourist resorts and also, different reporting patterns in which these resorts are framed, depending on the number and share of the tourism turnover from the total local economy.
\end{abstract}

Keywords: tourism, turnover, tourist resorts, structural analysis, Romania

\section{INTRODUCTION}

The tourism industry is one of the most important parts of the services sector and it is indeed an activity with considerable importance in the global economy [1]. In addition, it is expected that it will continue to grow at a faster rate than the average growth rate of the world economy, which will lead to the fact that tourism will be the largest industry in the world [2]. In fact, a number of studies confirm that this economic sector can bring significant benefits, both economically and socially [3]. Tourism is now an economic component that must be considered, a complementary sub-branch for the economic development of some territorial systems, especially those with specific resources [4]. The way in which the tourism sector can economically influence the territorial systems is a very important concern of today [5], [6], [7], [8]. This sector, being a socio-economic phenomenon, has in many cases become an engine of the economy, which has determined over time an increase of the functional complexity of the territorial systems that have resources that can be exploited [9], [10]. 
Considering the potential contribution of general economic recovery, tourism is approached as one of the priority sectors of the Romanian economy.

The turnover is one of the most important economic indicators used in quantifying the economic performance of a company, situation also encountered in the case of tourist activities, its value offering indices regarding the economic efficiency of the tourist resorts. From studies on tourism, it appears that this sector has the largest turnover in the world.

Through a management policy regarding the improvement of the services in the tourist resorts, together with an adequate marketing policy, the tourism field can bring economic benefits quite important for the community [11], [12] [13].

\section{METHODOLOGY}

In this study, we analysed all the tourist resorts from Romania, which are in accordance with the Government Decision No. 107 of 2018 approving the attestation of some localities or parts of localities as tourist resorts of national or local interest and on the change of annex no. 5 to the Government Decision no. 852 of 2008, to approve the rules and the attestation criteria of tourist resorts. In total, in Romania are 108 resorts (47 of national interest and 61 of local interest).

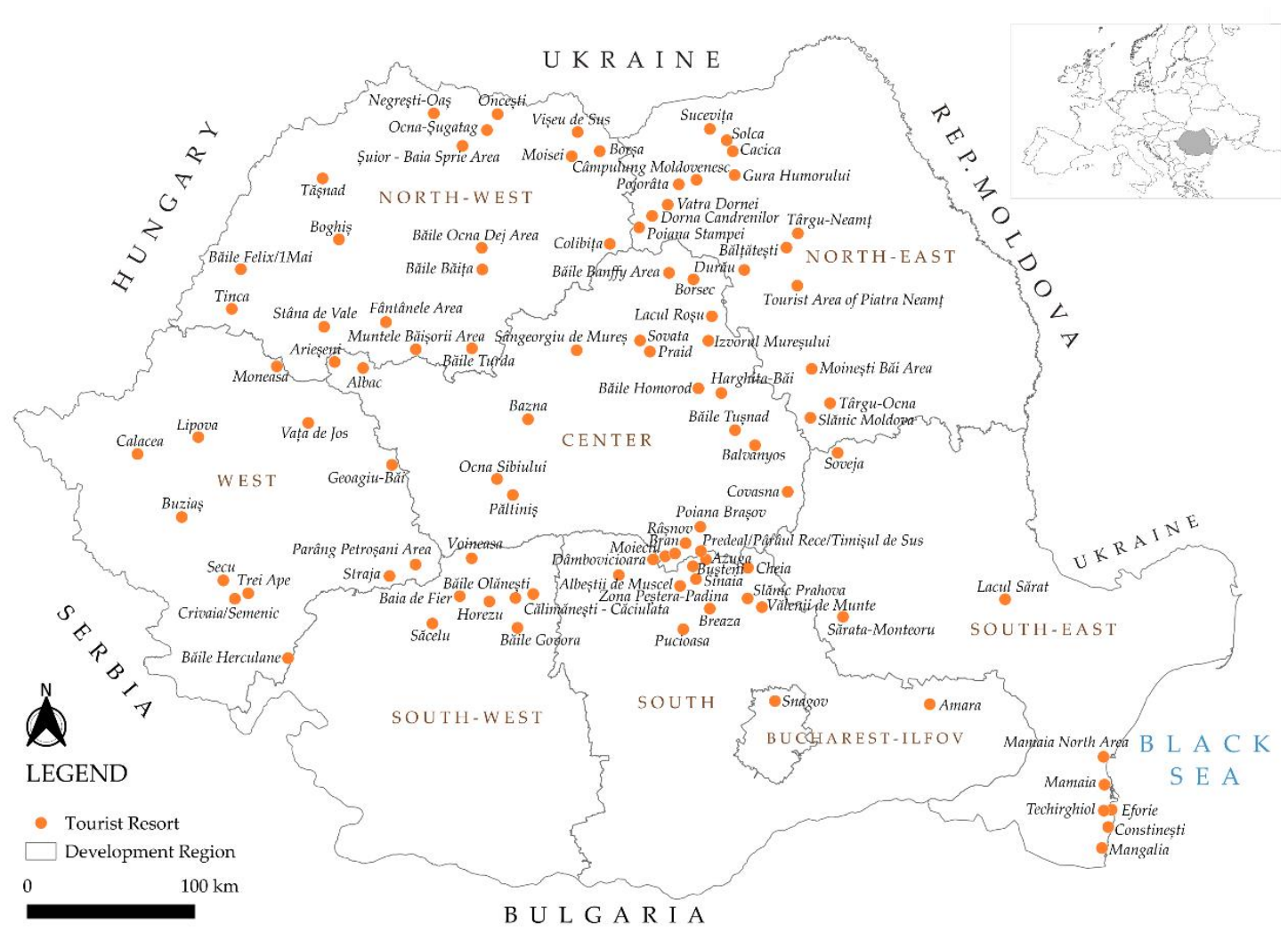

Figure 1. Distribution of tourist resorts in Romania

For these systems with tourist function, an economic database was created, both at the level of territorial administrative unit and at the level of four-digit NACE code (Classification of National Economy Activities), with an economic indicator that was considered relevant for this study, the turnover from the tourism sector, for a period of 19 years, ie 2000-2018. The database for the turnover was represented in Romanian currency, 
RON, where $1 \mathrm{RON}$ is equal to $0.28 €$ (euro), average course calculated for the period 2000-2018. For this indicator, graphical representations were made that analyze the evolution of the turnover in tourism and its share of the total economy, as well as its evolution by activity areas (by 4-digit NACE codes).

Also, there were made cartographic representations, which shows the distribution at the tourist resort level of the share of the turnover from tourism from the total turnover. These cartographic representations, as well as the one that shows the distribution of the tourist resorts in Romania (Fig. 1), were realized with the help of open-source QGis software.

\section{RESULTS}

In the tourist resorts from Romania, the total turnover follows an upward trajectory, with some fluctuations over the analysed periods. The increase that took place during the analyzed period was with $111,948,684,861$ Ron from 2000 to 2018 . The share of turnover from the tourism sector from total turnover is between $1.9 \%$, in 2015 and $3.2 \%$ in 2000 (Fig. 2).

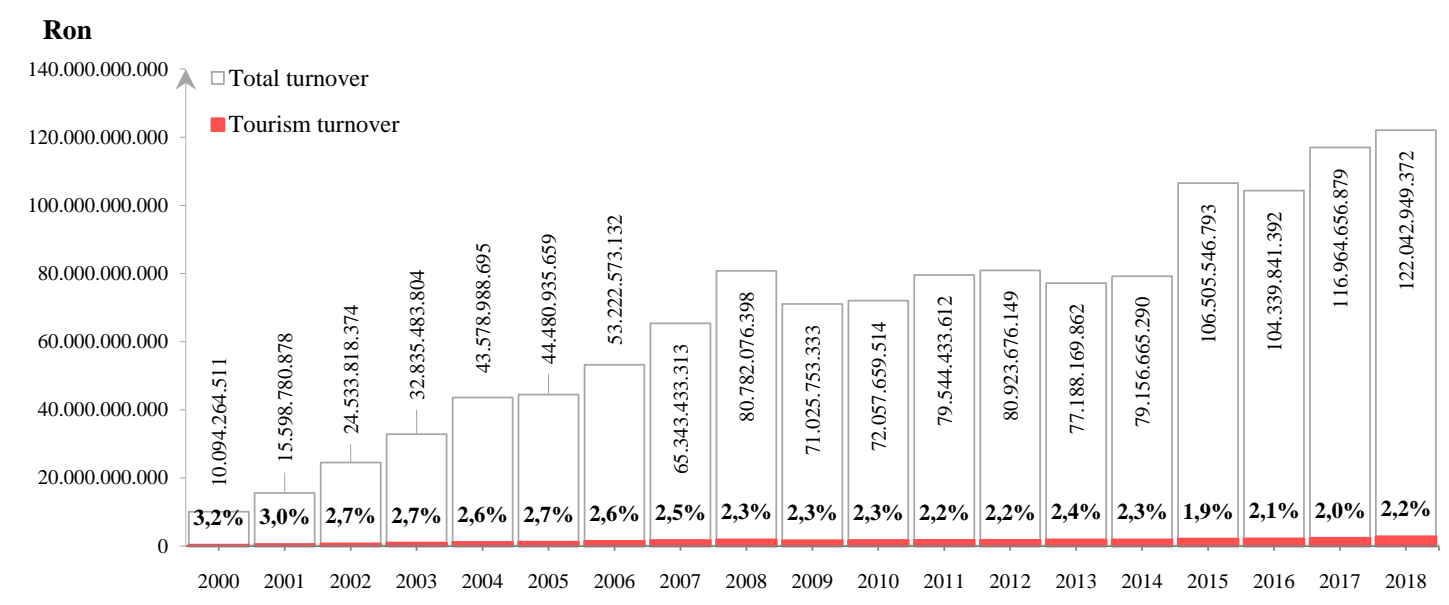

Figure 2. The evolution of the total turnover and the share of the turnover from tourism in tourist resort Source: Project UB 1423

The turnover in tourism shows an upward trend with fluctuations (Fig. 3). The only decrease in the tourism turnover during the whole period analyzed was in 2009, when it decreased by $13 \%$ compared to the previous year due to the global economic crisis that has made its mark on these resorts. After this period of decline, the turnover began to increase continuously, from year to year, so that in 2018 the highest turnover from tourism field was registered.

Figure 3 shows the evolution of the turnover by activity areas, ie four-digit NACE codes belonging to the tourism domain. There is a high concentration of turnover in hotels and similar accommodation. The evolution of this sector is an ascending one, the maximum value of the turnover registering in 2018, when it reached a value of 1,832,961,259 Ron, accounting for $67 \%$ of the total tourism turnover. The following areas that bring a significant turnover are 5590 - Other accommodation, which in 2018 brings a contribution of $8 \%$ to the total tourism turnover, 7911 - Travel agency activities, 5\%, 7990 - Other reservation service and related activities $4 \%$. 


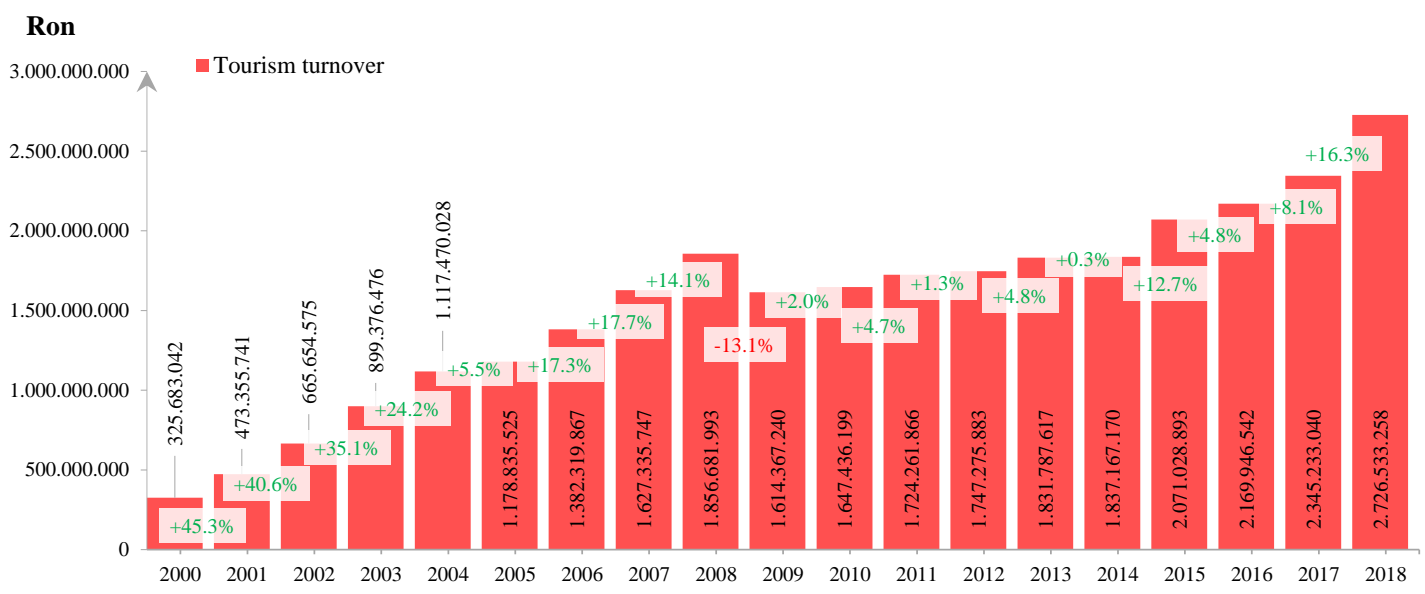

Figure 3. The evolution of the tourism turnover from the tourist resorts in Romania Source: Project UB 1423

The smallest turnover was recorded by Museums activities and Botanical and zoological gardens and nature reserves activities. This last NACE code registered values of the turnover only in 2 years of the 19 analyzed, 2010 and 2013 (Poiana Brașov resort).
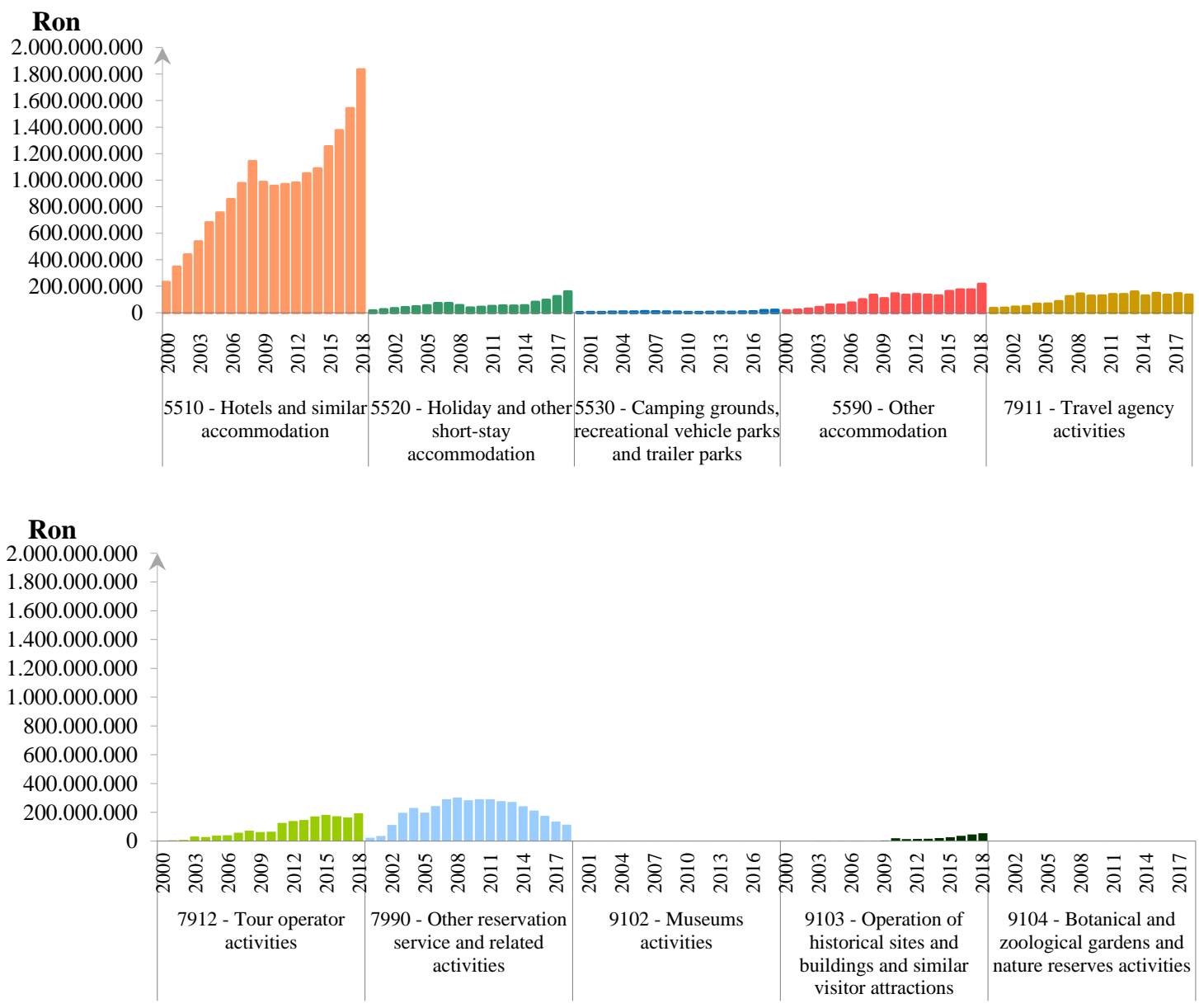

Figure 3. The evolution of the tourism turnover in the tourist resorts from Romania by activity sectors Source: Project UB 1423 

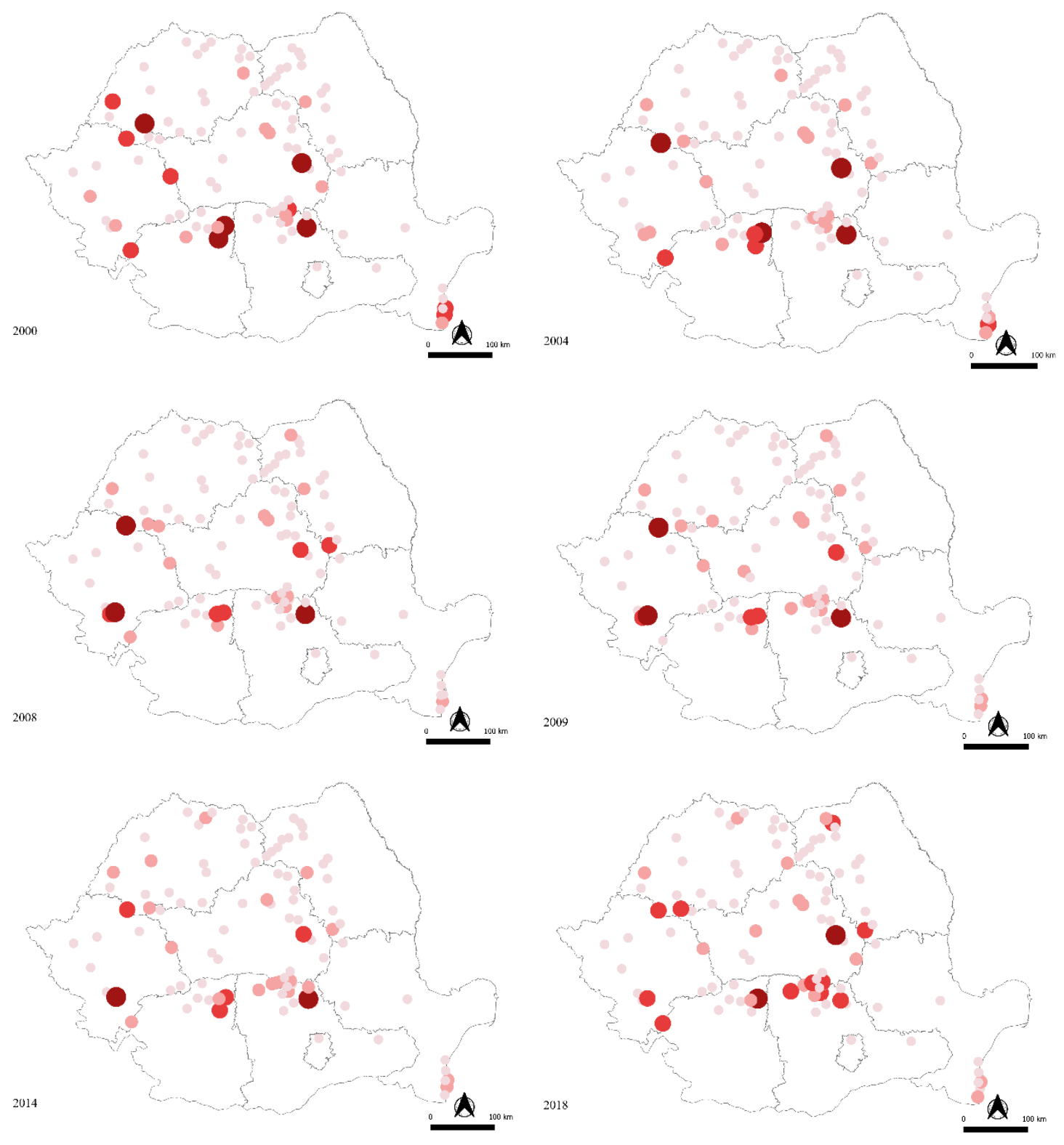

\section{LEGEND}

Share of tourism turnover
$0 \%-10 \%$
$10.1 \%-30 \%$
$30.1 \%-50 \%$
$50.1 \%-100 \%$

Figure 4. Distribution of the share of tourism turnover in total turnover, in tourist resorts from Romania in 2000, 2004, 2008, 2009, 2014 and 2018.

Source: Project UB 1423

The distribution of the share of the tourism turnover (Fig. 4), presents the way of evolution of this indicator in the tourist resorts in Romania for certain years: 2000, 2004, 2008 and 2009 (period of economic crisis), 2014 and 2018. Most resorts, in the year 2000, were in 
the category 0\% - 10\% (Snagov, Amara, Sucevița, Gura Humorului, Pucioasa, Breaza, Lacul Sărat etc.), and only 5 resorts have a share of turnover exceeding $50 \%$ of their economy (Băile Govora - 55,1\%, Băile Tuşnad - 77\%, Călimănești-Căciulata - 54,5\% , Slănic Prahova $-72 \%$ and Stâna de Vale with $71 \%$ ). For the other categories, between $10.1 \%$ and $30 \%$ and between $30.1 \%$ and $50 \%$, there were 12 resorts, respectively 7 .

In 2004, the share of tourism turnover for the Govora resort decreased to 38\%, while the number of resorts with share between $30.1 \%$ and $50 \%$ decreased. In the period 2008 2009, of the 108 resorts present at the level of Romania, only 3 has a share of tourism turnover over 50\%, namely: Slănic Prahova, Moneasa and Trei Ape (resort of local interest, whose economy is largely based on the tourism sector).

The year 2008 brings increases among the resorts whose share of tourism turnover is between $30.1 \%$ and $50 \%$ (11 resorts), and a decrease of those with a share of over $50 \%$ (compared to 2000, when there were 5 resorts, in 2018 there are only 2 - Băile Tușnad and Călimănești-Căciulata).

\section{CONCLUSIONS}

The results obtained from the analysis, bring an increase in the economic part of the tourist resorts from Romania (the 108 resorts that are in accordance with the Government Decision No. 107 of 2018) and a better understanding of how the tourism sector works, from the point of view of turnover.

The analysis shows a continuous increase of this indicator for the territorial systems with tourist function throughout the 19 years analyzed, with a slight decrease due to the economic crisis. The highest value of turnover is given by the activity of hotels and other accommodation facilities (NACE code 5510), the domain that owns, over the analyzed period, over $55 \%$ of the tourism turnover. From the distribution of the share of the turnover, the resorts Moneasa, Băile Tușnad, Slănic Prahova, Trei Ape, CălimăneștiCăciulata, are highlighted, as having a share of tourism turnover of over $50 \%$. For these resorts, tourism is the main sector in their economy. Most resorts from the level of Romania were in the category $0 \%-10 \%$, showing that for them, tourism represents a complementary part in the economy.

In order to maximize the beneficial effects for the development of the tourist activities, the management strategies are highlighted as one of the modalities, in the same category entering the activities that are given by the tourism development [14], [15], [16], [17], [18].

\section{Acknowledgement}

This paper is co-financed from the Human Capital Operational Program 2014-2020, project number POCU / 380/6/13/125245 no. 36482 / 23.05.2019 "Excellence in interdisciplinary $\mathrm{PhD}$ and post-PhD research, career alternatives through entrepreneurial initiative (EXCIA)", coordinator The Bucharest University of Economic Studies".

\section{REFERENCES}

[1] Kavaliauske M. \& Kocyte R. Sustainable tourism development in Neringa region, 19th International Scientific Conference; Economics and Management, Latvia, 2014, pp 208-2012;

[2] Fauzel S., Seetanah B. \& Sannassee R.V. Analysing the impact of tourism foreign direct investment on economic growth: Evidence from a small island developing state, Tourism Economics, pp 1-14, 2016. 
[3] Drăghici C. C., Diaconu D., Teodorescu C., Pintilii R. D. \& Ciobotaru A. M. Health tourism contribution to the structural dynamics of the territorial systems with tourism functionality, Procedia Environmental Sciences, vol. 32, pp 386-393, 2016.

[4] Pintilii R.D., Peptenatu D., Grecu A., Ilie A.M. \& Simion A.G. Tourism, basic functionality versus complementary component of the territorial systems in Romania. International Conference - Environment at a Crossroads: SMART approaches for a sustainable future, 2016, pp 364-372.

[5] Pratt S. The economic impact of tourism in SIDS, Annals of Tourism Research, vol. 52, pp 148-160, 2015.

[6] Kim H. \& Uysal M. Life satisfaction and support for tourism development, Annals of Tourism Research, vol.50, pp 84-97, 2015.

[7] Syzdykbayeva B., Raimbekov Z., Khydyrbekuly D., Temirbulatova M. \& Bayandinova A. Research note: Evaluation and projection of economic indicators of tourism development in Kazakhstan, Tourism Economics, vol. 21, vol. 1315-1322, 2015.

[8] Blake A. The dynamics of tourism's economic impact, Tourism Economics, vol. 15 pp 615628, 2009.

[9] Grechi D., Ossola P. \& Tanda A. The european tourism industry in crisis: a stock market perspective, Tourism Analysis, vol. 22, pp 139-148, 2017.

[10] Lopez Morales J.M. \& Such Devesa M.J. Business cycle and external dependence on tourism: Evidence for Spain, Tourism Economics, vol. 23, pp 187-199, 2015.

[11] Mueller H. \& Kaufmann E.L. Wellness tourism: Market analysis of a special health tourism segment and implications for the hotel industry, J. Vacat. Mark., vol. 7, 2001.

[12] Drăghici C.C., Pintilii R.D., Peptenatu D., Comănescu L.G. \& Sirodoev I. The Role of SPA Tourism in the Development of Local Economies from Romania, $2^{\text {nd }}$ Global conference on Business, Economics, Management and Tourism, Prague, Czech Republic, 2014, pp 1573-1577.

[13] Grecu A., Gruia A.K., Marin M., Bănuță M., Olteanu C., Constantin I., Gadoiu M., Teodorescu C., Dobrea C.R. \& Drăghici C.C. Specificity of sustainable structural dynamics of local economy in Romanian tourist resort, Sustainability, vol. 11, 2019.

[14] Peptenatu D., Merciu C., Merciu G., Drăghici C. \& Cercleux L. Specific features of environment risk management in emerging territorial structures, Carpathian Journal of Earth and Environmental Sciences, vol. 7, pp 135-143, 2012.

[15] Peptenatu D., Draghici D. \& Merciu C. Characteristics of entrepreneurial profile in some emergent territorial structures in Romania, Actual Problems of Economics, vol. 12, pp 448-458, 2012.

[16] Pintilii R.D., Peptenatu D., Ciobotaru A.M., Toma S.G., Grigore A.M., Drăghici C. C., Dobrea R.C., Simion A.G., Andronache I., Teodorescu C. \& Diaconu D.C. Creative economies in Romania - spatial projections and trends, Bulletin of Geography-Socio-Economic Series, vol. 37, pp 95-108, 2017.

[17] Drăghici C.C., Andronache I., Ahammer H., Peptenatu D., Pintilii R.D., Ciobotaru A.M., Simion A.G., Dobrea R.C., Diaconu D.C., Vişan M.C. \& Papuc R.M. Spatial evolution of forest areas in the northern Carpathian Mountains of Romania, Acta Montanistica Slovaca, vol. 22, pp 95-106, 2017.

[18] Gruia A. K., Dobrea R.C., Simion C.P., Dima C., Grecu A., Hudea O.S., Marin M., Andronache I. \& Peptenatu D. The Use of Sholl and Kolmogorov Complexity Analysis in Researching on the Sustainable Development of Creative Economies in the Development Region of Bucharest-Ilfov, Romania, Sustainability, vol. 11, 2019. 